\title{
A felületaktivált XII-es véralvadási faktor életkortól függő lehetséges szerepe a „bradikininvihar” kialakításában COVID-19-betegekben
}

\author{
Sipka Sándor dr. ${ }^{1}$ - Tóth Attila dr. ${ }^{2}$ - Sipka Sándor jr. dr. ${ }^{3}$ \\ ${ }^{1}$ Debreceni Egyetem, Általános Orvostudományi Kar, Klinikai Immunológiai Tanszék, \\ Belgyógyászati Intézet, Debrecen \\ ${ }^{2}$ Debreceni Egyetem, Általános Orvostudományi Kar, Klinikai Fiziológiai Tanszék, Debrecen \\ ${ }^{3}$ Debreceni Egyetem, Általános Orvostudományi Kar, Kardiológiai Intézet, Kardiológiai Tanszék, Debrecen
}

Bevezetés: Egy új, számítógép által segített betegminta-asszociációs analízis eredménye szerint a COVID-19 tüneteinek kialakításában kiemelt tényezőként jelenik meg a bradikinin. Eszerint a bradikinin lebontása lelassul az angiotenzinkonvertáló enzim aktivitásának csökkenése miatt, ami jelentősen megemelkedő bradikininszinthez vezet a tüdőben. Nem merült fel azonban a véralvadási faktorok lehetséges szerepe a „bradikininviharban”, annak ellenére, hogy az idősebb cardiovascularis betegekben aktiválódó XII-es faktor és a Cl-észteráz-inhibitor $(\mathrm{C} 1 \mathrm{INH})$ alacsony szintje nagy mennyiségü bradikinin képződéséhez vezethet.

Módszer: Átfogó irodalmi áttekintés.

Eredmények: 1) A vírus által fertózött, sérült endotheliumsejtek felülete az a hely, amellyel érintkezve elindulhat a XII-es véralvadási faktor aktivációja - ez serkenti a prekallikrein/kallikrein/kinin rendszert, és bradikininképződést okoz. Ez a folyamat megtörténik a súlyos vese- és tüdőkárosodást okozó hantavírus-fertőzésekben. 2) Idős betegekben az atherosclerosis miatt többszörösen sérült, merev, „stiff” erek endotheliumfelszínein jóval magasabb lehet a XII-es faktor kontakt úton történő aktivációja, mint a fiatal egyének ereiben. Ez a tény egyik oka lehet az idős, cardiovascularis betegek körében tapasztalt magasabb halálozásnak.

Követheztetés: Az aktivált XII-es véralvadási faktor célzott gátlása újabb gyógyítási lehetőség lehet a SARS-CoV-2-fertőzött idős betegekben. Jelenleg már hatásosnak bizonyult a bradikininképzést gátló ClINH-nak, továbbá a bradikininreceptor-gátlóknak az adása is.

Orv Hetil. 2020; 161(50): 2099-2103.

Kulcsszavak: bradikinin, bradikininreceptor-antagonista, COVID-19, Cl-észteráz-inhibitor, XII-es véralvadási faktor

Age-dependent possible role of contact-activated blood coagulation factor XII as a potential contributor to the "bradykinin storm" in COVID-19 patients

Introduction: Bradykinin was implicated in a new complex model of pathomechanism leading to the symptoms of COVID-19 created by a computer-assisted association analysis. According to this model, the decrease in angiotensinconverting enzyme expression leads to impaired bradykinin elimination and subsequent enrichment in the lungs. However, there is no mentioning of the importance of blood coagulation factor XII in increased bradykinin production, in spite of its age-dependent activation and the lower level of $\mathrm{Cl}$-esterase inhibitor $(\mathrm{ClINH})$. Activated factor XII may be an important contributor to the "bradykinin storm" in elder cardiovascular patients.

Method: Literature review.

Results: 1) Activation of the coagulation factor XII on the surface of SARS-CoV-2 infected endothelial cells may trigger the prekallikrein/kallikrein/kinin system producing bradykinin. Such process is taking place in hantavirus infections causing severe lung and kidney damages. 2) The endothelial system is dysregulated in elderly patients, resulting in potentially higher factor XII activities on the surface of damaged endothelial cells in the stiffened arteries. This can contribute to the higher mortality rates in the elderly. 
Conclusion: The targeted inhibition of activated blood coagulation factor XII may represent a new therapeutic target for COVID-19, especially for elder patients. Recently, beneficial results have already been observed by the clinical applications of recombinant $\mathrm{ClINH}$ and bradykinin receptor antagonists.

Keywords: bradykinin, bradykinin receptor antagonist, COVID-19, Cl-esterase inhibitor, blood coagulation factor XII

Sipka S, Tóth A, Sipka S Jr. [Age-dependent possible role of contact-activated blood coagulation factor XII as a potential contributor to the "bradykinin storm" in COVID-19 patients]. Orv Hetil. 2020; 161(50): 2099-2103.

(Beérkezett: 2020. szeptember 28.; elfogadva: 2020. október 21.)

\section{Rövidítések}

$\mathrm{ACE}=$ (angiotensin-converting enzyme) angiotenzinkonvertáló enzim; ADAMTS13 = $($ a disintegrin and metalloproteinase with a thrombospondin type 1 motif, member 13) az ADAMTS-család (dezintegráló és metalloproteináz enzim tromboszpondin motívummal) 13 -as tagja ; ClINH = Cl-észteráz-inhibitor; $\mathrm{CD}=$ (cluster of differentiation $)$ differenciációs klaszter; COVID-19 = (coronavirus disease 2019) koronavírus-betegség 2019; SARS-CoV-2 = (severe acute respiratory syndrome coronavirus 2) súlyos akut légúti tünetegyüttest okozó koronavírus-2

A COVID-19-világjárvány második hullámában vagyunk. A vírus kutatásában, a betegek kezelésében, az új gyógyszerek kifejlesztésében globális összefogás tapasztalható. Folyamatosan jelennek meg újabb és újabb közlemények. Alapvető felismerésnek számít, hogy a 2-es típusú angiotenzinkonvertáló enzim (ACE2 ), amely egy membránhoz kötött metallokarboxipeptidáz, a receptora a COVID-19-et okozó vírusnak, így az egyik célmolekulája is a fertózések gyógyításának [1]. Az utóbbi hetek eredményeiból kiemelkedik Daniel Jacobson és mtsai közleménye [2, 3]. Eredményeiket a „Summit” nevú szuperkomputer segítségével nyerték több, eredetileg a SARS-CoV-2 genomjának meghatározásához használt, elsőként azonosított kínai fertőzöttek mintáinak elemzésével. A számítógépes algoritmus a minták analízisére épülve több mint tízezer gén kifejeződését tartalmazta. Felfedezésük lényege, hogy a COVID-19 tüneteinek hátterében talán fontosabb a „bradikininvihar”, mint az eddig ismert „citokinvihar”.

A COVID-19-et okozó vírussal fertőzött betegek hörgőmosó folyadékából származó sejtekben végzett genetikai asszociációs analízis a következő felismeréseket hozta: (A) a már korábban ismert úton, a sejtfelszíni ACE2-molekulához kötődés után a sejtbe bejutó vírus megemeli az ACE2, a renin, az angiotenzin, a kallikrein, továbbá az angiotenzin- és a bradikininreceptor termelődését, és csökkenti a bradikininlebontó ACE szintjét. Ugyanakkor az ACE2 egyik terméke, az angiotenzin ${ }_{1-7}$ több áttétel után fokozza a bardikininprodukciót. Mindez együttesen hatalmas mennyiségű bradikininképződést okozhat „viharszerüen”, ami jelentős értágulatot, foko- zott érpermeabilitást és vérnyomáscsökkenést válthat ki. Hangsúlyozni kívánjuk, hogy jelentősen lecsökken a Clészteráz-inhibitor (CIINH) képződése is, amely közvetlenül gátolná a XII-es faktor aktiválódását, továbbá a bradikinin képződését kallikrein útján. (B) A megnőtt hialuronsav és a csökkent hialuronidáztermelés a fertőzött tüdő alveolusaiban „hialuronsav-hidrogél” képződését váltja ki, ami akadályozza a gázcserét [2].

Korábbi megfigyelések leírták, hogy komoly véralvadási zavarok lépnek fel COVID-19-fertőzésekben, például hypercoagulopathia, majd disszeminált intravascularis coagulopathia alakul ki [4], továbbá thrombocyta- és endotheliumaktiváció történik, a plazmában emelkedik a Von Willebrand-faktor, a szolúbilis trombomodulin, a Pszelektin és a CD40 szintje [5]. Endotheliitis jön létre $[6,7]$.

Az irodalomban ugyanakkor a károsodott, gyulladásos érfalfelülettel történő érintkezés útján aktiválódó XII-es véralvadási faktor szerepe eddig még nem került említésre. Véleményünk szerint azonban a „bradikininelmélethez" illeszthetően valószínúsíthető, hogy COVID-19 során, különösen időskor és atherosclerosis esetén, aktiválódhat a véralvadás mindkét útja [8]: a szöveti faktor és a VII-es faktor által elindított trombin- és fibrinképződés (extrinszik út) és a XII-es faktor kontaktaktivációja útján induló trombin- és fibrinképződés (intrinszik út), továbbá a kallikrein által képzett bradikinintermelődés [8].

\section{Módszer}

Átfogó irodalmi áttekintés.

\section{Eredmények}

Az 1. ábra mutatja, hogy a COVID-19-et okozó vírus az ACE2-molekulához mint receptorához kapcsolódva jut az érfal endotheliumsejtjeibe, amelyek azonban ép állapotban fiataloknál a felszínükön erősen negatív töltésû hordozómolekulákat, például glükózamin-glükánszulfátot hordoznak. Ez megakadályozza a XII-es faktor kötődését. Az érfal rugalmasságát az endothelium alatt elhelyezkedő elasztikus rostok és simaizomsejtek adják. Kollagénrostok az ezek alatti rétegben vannak [9]. A fo- 


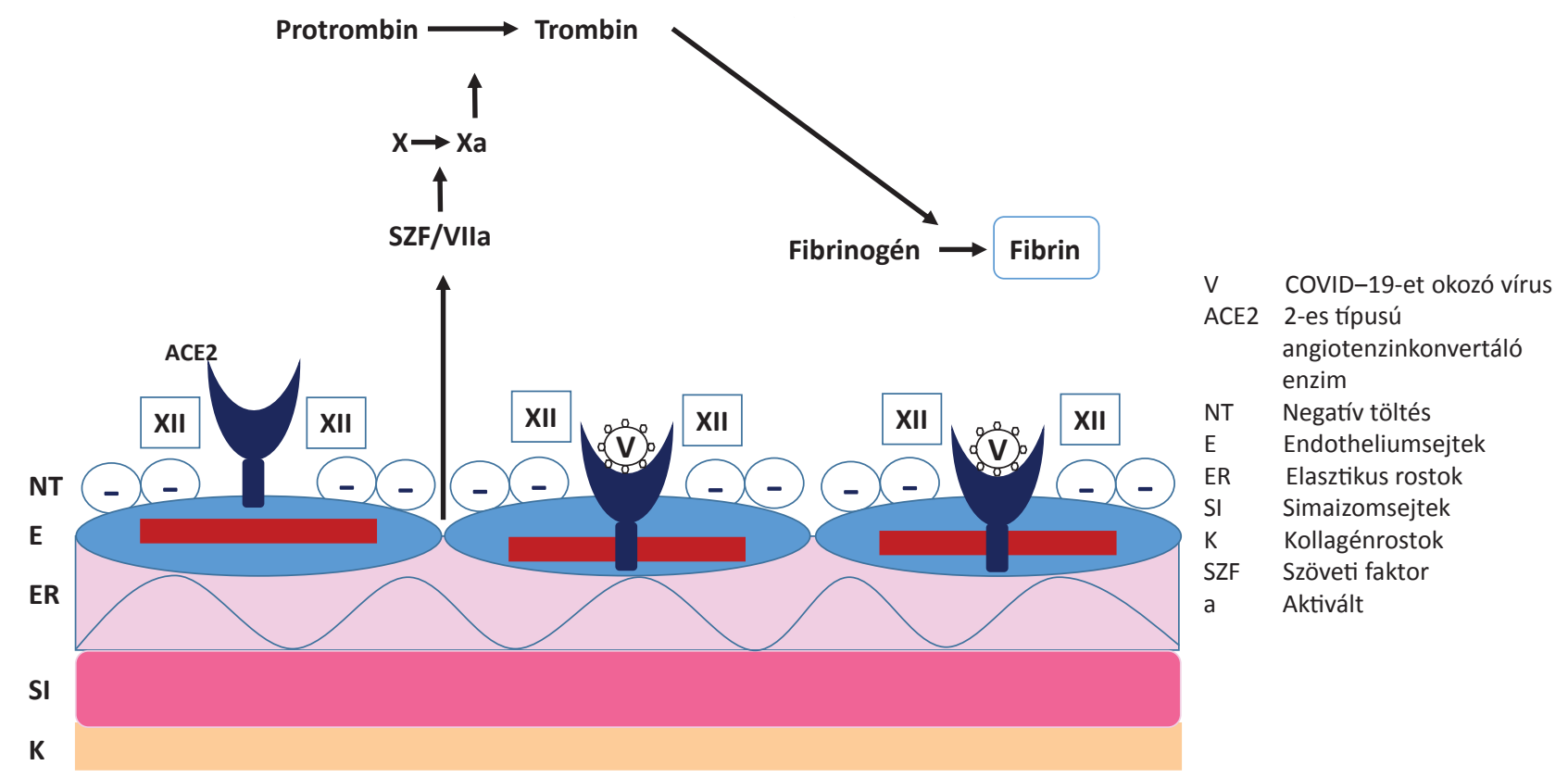

1. ábra A véralvadás, fibrinképződés folyamatai nem szklerotikus artériafalban COVID-19-fertőzésben
COVID-19 = koronavírus-betegség 2019

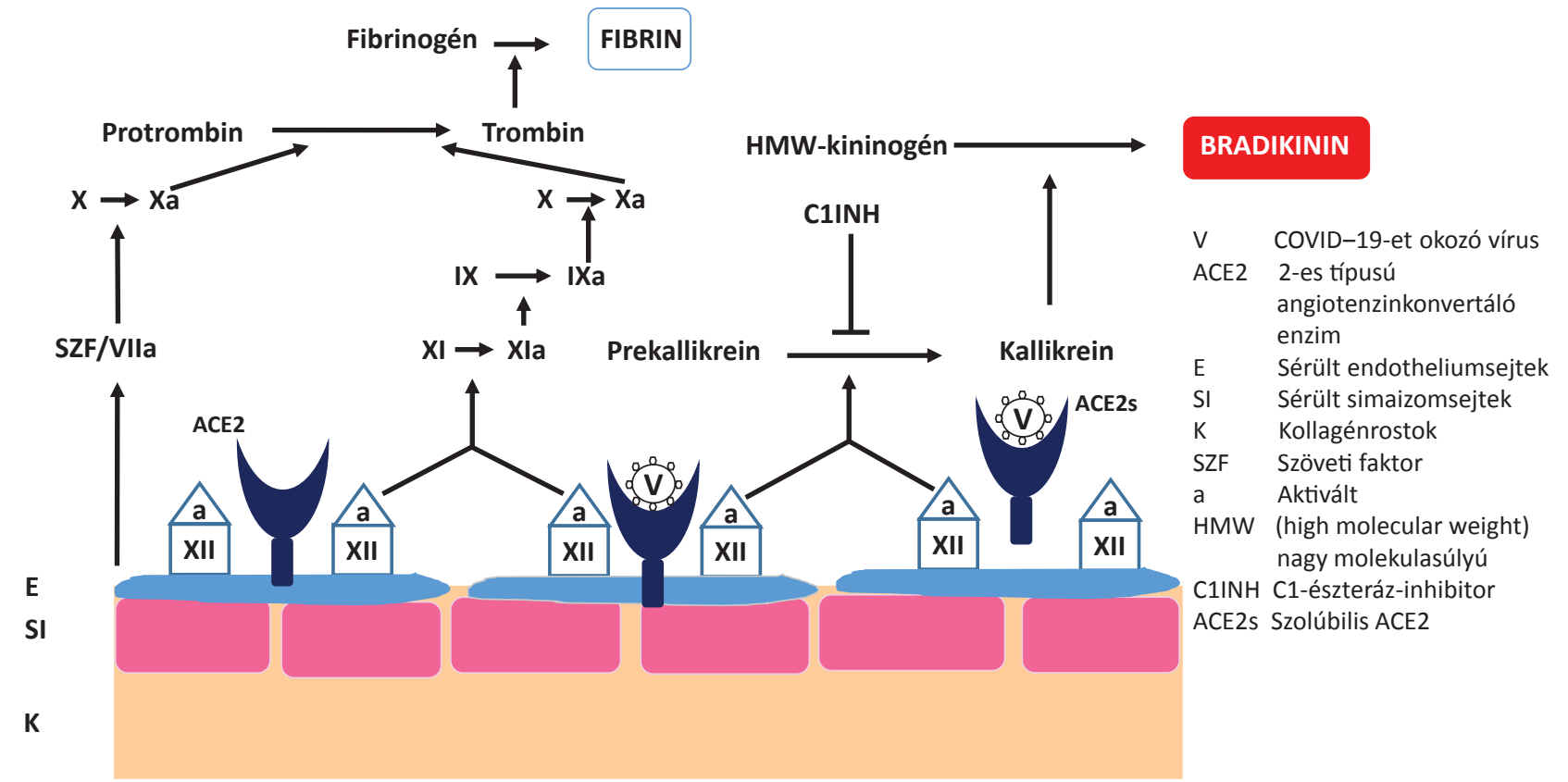

2. ábra

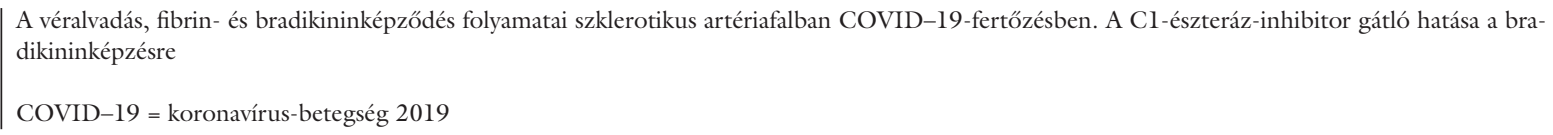

kozott véralvadáshoz szükséges „szöveti faktor” képződését a behatoló vírus által kiváltott endotheliitis $[6,7]$ juttatja a keringésbe, ami a VII-es és a X-es faktor aktiválása útján hozza létre a trombint és a fibrint (1.ábra).

Az idős személyekben - különösen, akiknél súlyos atherosclerosis alakul ki hypertonia vagy diabetes következtében - már létrejönnek az érfalban a XII-es faktor aktiválódásának feltételei: (A) az endothelium sejtjei ká- rosodnak, felszínük elveszti a negatív töltésú molekuláit; (B) az elasztikus rostok eltünnek a subendotheliumrétegból; (C) a simaizomréteg integritása megszúnik; (D) az érfal kollagénrostokkal telítődik [9], merevvé válik, artériás merevség (stiffness) alakul ki [10]; (E) a sérült endotheliumfelszínen aktiválódik a XII-es faktor (XIIa), ami a trombinképzés útján tovább növeli a párhuzamosan múködő extrinszik út fibrinmennyiségét, emellett a 
prekallikrein/kallikrein úton bradikinintermelést [8] vált ki. Ez a jelentősen megemelkedett bradikininmennyiség tovább ronthatja a COVID-19-ben szenvedő idős betegek állapotát. Ezért kézenfekvő lehetőségnek kínálkozik ilyen esetekben a korábban említett alacsony CIINHszint [2] megemelése a gyakorlatban és forgalomban használt, különböző rekombináns CIINH-készítmények alkalmazásával, melyek a prekallikrein-kallikrein út gátlásával csökkenthetik a bradikininképződést [11-13]. Mindemellett saját munkánk során 46 idős szívbetegnél szignifikánsan emelkedett szolúbilis ACE2-szinteket találtunk [14]. Véleményünk szerint ennek komoly kihatása lehet a bradikinin-anyagcserére. Ebben a helyzetben az ACE2-receptoroknak három formája fordul elő: (A) érintetlen, (B) víruskötő, sérült endotheliumba fordult, (C) víruskötő, szolúbilis ACE2 (2. ábra).

\section{Megbeszélés}

A bemutatott eredmények szerint a COVID-19-fertőzésekben megfigyelt hypercoagulopathia létrejötte során a véralvadás két útvonala különböző módon aktiválódik. A még viszonylag ép, fiatal, egészséges egyének artériáinak endotheliumsejtjein az extrinszik út jellemző. Az elmeszesedett, időskori erekben azonban létrejöhet a XII-es faktor aktiválódása a többszörösen sérült érfalakban. Ez fokozott bradikinintermelést is okoz, ami hozzájárulhat az újabban felmerült „bradikininvihar” kialakulásához [2, 3]. A COVID-19 vonatkozásában ez új megközelítésnek számít, ugyanakkor hasonló mechanizmus már leírásra került korábban a haemorrhagiás lázzal és renalis szindrómával járó hantavírus-fertőzésben [15]. A COVID-19-fertőzésekben kialakuló „bradikininvihar" lecsendesítésének leggyorsabban kipróbálható új oki terápiáját a különböző C1INH-készítmények és bradikininantagonista gyógyszerek jelenthetik [11-13]. Ugyanakkor nem lehet figyelmen kívül hagyni azt a fontos hazai megfigyelést, hogy a komplementrendszer, az ADAMTS13 aktivitása is jelentős változáson megy keresztül [16, 17], a ClINH-készítmények ezekre is kedvezőek lehetnek. Végül, a szolúbilis ACE2 emelkedésére vonatkozó eredményeink [14] új szempontú adalékot szolgáltatnak annak magyarázatához, hogy idős, cardiovascularis COVID-19-betegeknél miért alakulhat ki súlyosabb „bradikininvihar”, mint fiatalabbakban. Véleményünk szerint a vírussal szolúbilis közegben reagáló ACE2 képzése a szervezet védekezésének egy lehetséges formája, mivel a vérben megkötött vírus nem képes a sejteket fertőzni (ez kedvező); másrészt azonban a sejtek felszínéhez kötött ACE2 elvesztése megnöveli a bradikininszinteket, különösen a tüdőben, ami fokozza a gyulladást. Ez is magyarázhatja, hogy az idős és a fiatal betegek kezelésének számos eltérése van [18], melyeket tovább színezhet az ACE2-polimorfizmus felismerése [19].

\section{Következtetés}

Egyre több adat erősíti meg, hogy a XII-es faktor aktiválódásának mértéke emelkedik időskorban, továbbá arányos a cardiovascularis betegségek súlyosságával. Ez a folyamat a fokozott bradikininképzés útján hozzájárulhat a COVID-19 során jelentkező súlyosabb gyulladások, különösen a tüdőgyulladás megjelenéséhez. Ez az összefüggés azért fontos, mert ennek értelmében a XII-es faktor aktivitását gátló gyógyszerek és kezelések hatékonyak lehetnek a COVID-19 súlyos tüneteinek (tüdőgyulladás, hypotonia és hypercoagulopathia) megelőzésében vagy gyógyításában. Ilyen hatású molekulák keresése is több irányban folyik [20]. Ugyanakkor már klinikai kipróbálás alatt állnak eljárások, kezelési formák, melyek alkalmasak lehetnek ezen útvonal gátlásával a COVID-19 tüneteinek enyhítésére. Ilyenek a CIINHkészítmények és a bradikininreceptor-antagonisták [12].

Anyagi támogatás: A szerzók anyagi támogatásban nem részesültek.

Szerzői munkamegosztás: S. S.: Levelező szerző, a cikk megírása. T. A., S. S. jr.: A kézirat véleményezése és kiegészítése. A koncepció kialakításában mind a három szerző részt vett. A cikk végleges változatát valamennyi szerző elolvasta és jóváhagyta.

Érdekeltségek: A szerzőknek nincsenek érdekeltségeik.

\section{Irodalom}

[1] Roshanravan N, Ghaffari S, Hedayati M. Angiotensin converting enzyme-2 as therapeutic target in COVID-19. Diabetes Metab Syndr. 2020; 14: 637-639.

[2] Garvin MR, Alvarez C, Miller JI, et al. A mechanistic model and therapeutic interventions for COVID-19 involving a RAS mediated bradykinin storm. eLife 2020; 9: e59177. DOI: 10.7554/ eLife.59177.

[3] Smith T. A supercomputer analyzed Covid-19 - and an interesting new theory has emerged. Sept 1, 2020. Available from: https://elemental.medium.com/a-supercomputer-analyzedcovid-19-and-an interseting-new-theory-has-emerged-31cb8eba9d63

[4] Goshua G, Pine AB, Meizlish ML, et al. Endotheliopathy in COVID-19 associated coagulopathy: evidence from a singlecentre, cross-sectional study. Lancet Haematol. 2020; 7: E575E582.

[5] Terpos E, Ntanasis-Stathopoulos I, Elalamy I, et al. Haematological findings and complications of COVID-19. Am J Hematol. 2020; 95: 834-847.

[6] Varga Zs, Flammer AJ, Steiger P, et al. Endothelial cell infection and endotheliitis in COVID-19. Lancet 2020; 395: 1417-1418.

[7] Huertas A, Montani D, Savale L, et al. Endothelial cell dysfunction: a major player in SARS-CoV-2 infection (COVID-19)? Eur Respir J. 2020; 56: 2001634.

[8] Fonyó A. Haemostasis. In: Fonyó A. (ed). Textbook of medical physiology. [Vérzéscsillapodás. In: Fonyó A. (szerk.) Az orvosi élettan tankönyve.] Medicina Könyvkiadó, Budapest, 2011; pp. 615-638. [Hungarian]

[9] Sima AV, Stancu C, Simionescu M. Vascular endothelium in atherosclerosis. Cell Tissue Res. 2009; 335: 191-203. 
[10] Hansen L, Taylor WR. Is increased arterial stiffness a cause or consequence of atherosclerosis? Atherosclerosis 2016; 249: 226 227.

[11] Naro GR, Noverati N, Craig T. The role of Cl-esterase inhibitors in the management of vasogenic edema in glioblastoma. Case Rep Med. 2020; 2020: 7981609.

[12] Mansour E, Palma AC, Ulaf RG, et al. Pharmacological inhibition of the kinin-kallikrein system in severe COVID-19. A proof of concept study. medRxiv BMJ Yale, 2020. 08. 11. DOI: https://doi.org/10.1101/2020.08.11.20167353

[13] Meini S, Zanichelli A, Sbrojavacca R, et al. Understanding the pathophysiology of COVID-19: could the contact system be the key? Front Immunol. 2020; 11: 2014.

[14] Fagyas M, Kertész A, Mányiné Siket I, et al. Level of the SARS CoV-2 receptor ACE2 is highly elevated in old aged patients with aortic stenosis: implications for ACE2 as a biomarker for the severity of COVID-19. Cardiac Cardiovasc Syst Infect Dis. 15 Jun 2020. DOI: 10.21203/rs.3.rs-34549/vl.

[15] Taylor SL, Wahl-Jensen V, Copeland AM. Endothelial cell permeability during hantavirus infection involves factor XII-dependent increased activation of the kallikrein-kinin system. PLoS Pathog. 2013; 9: e1003470.

[16] Mező B, Sinkovits G, Réti M, et al. Change in complement-profile in SARS-COV-2 infection tested in hospitalized patients. [A komplementprofil változása SARS-COV-2 fertőzés miatt kórházban kezelt betegekben.] MIT kongresszusi összefoglaló. Immunol Szle. 2020; 12: 16. [Hungarian]

[17] Sinkovits G, Mező B, Réti M, et al. ADAMTS-13 activity as a global marker of SARS-COV-2 infection reflecting the severity of disease for hospitalized patients. [Az ADAMTS 13 aktivitás mint a COVID-betegség súlyosságát jelző globális marker SARSCOV-2-fertőzés miatt kórházban kezelt betegekben.] MIT kongresszusi összefoglaló. Immunol Szle. 2020; 12: 17. [Hungarian]

[18] Behl T, Kaur I, Bungau S, et al. The dual impact of ACE2 in COVID-19 and ironical actions in geriatrics and pediatrics with possible therapeutic solutions. Life Sci. 2020; 257: 118075.

[19] Devaux CA, Rolain JM, Raoult D. ACE2 receptor polymorphism: susceptibility to SARS-CoV-2, hypertension, multi-organ failure, and COVID-19 disease outcome. J Microbiol Immunol Infect. 2020; 53: 425-435.

[20] Wilbs J, Kong XD, Middendorp SJ, et al. Cyclic peptide FXII inhibitor provides safe anticoagulation in a thrombosis model and in artificial lungs. Nat Commun. 2020; 11: 3890.

(Sipka Sándor dr., Debrecen, Móricz Zs. u. 22., 4032 e-mail: sipka.sandor45@gmail.com)

\section{"Discipulus est prioris posterior dies." (Tanítványa egyik nap a másiknak.)}

A cikk a Creative Commons Attribution 4.0 International License (https://creativecommons.org/licenses/by/4.0/) feltételei szerint publikált Open Access közlemény, melynek szellemében a cikk bármilyen médiumban szabadon felhasználható, megosztható és újraközölhető, feltéve, hogy az eredeti szerző és a közlés helye, illetve a CC License linkje és az esetlegesen végrehajtott módositások feltüntetésre kerülnek. (SID_1) 